\title{
Identification of Mutual Funds Investing in Tehran Stock Exchange
}

\author{
Zaffer Najafi (corresponding author) \\ Lecturer Department of Accounting, darehshahr Branch \\ Islamic Azad University, darehshahr, Iran \\ Tel:98-918-345-5086_E-mail: Najafi_zafar1363@yahoo.com \\ Heshmatollah Asgari \\ Assistant Professor in Economic, Ilam University, Ilam, Iran \\ E-mail: he.asgari@gmail.com \\ Mohammad Bandari \\ Department of industrial management \\ Payam noor University, POX 19395-3697 tehran, Iran \\ E-mail: mohamadbandari@yahoo.com
}

Received: May 22, 2013

doi:10.5296/jmr.v5i3.3742
Accepted: July 11, $2013 \quad$ Published: July 11, 2013

URL: http://dx.doi.org/10.5296/jmr.v5i3.3742

\begin{abstract}
Mutual Funds is a specialized financial institution that is invested by funds investors in diversed portfolio of investment securities, in return their investment units assigned to them. Each unit of investment fund is the relative representation of securities that is bought or managed on behalf of investers. Mutual fund as one of the most important financial intermediares are responsible to the transfer of weelth from consumers (society) to the resource owners (manufacturing and service companies, and others). With the creation of common investment funds, due to professional management and investment strategies, according to willingness and ability to take risks, investors have been able to enter the house of investors and capital market participants by management fee of common investment funds.
\end{abstract}




\section{Macrothink}

Journal of Management Research ISSN 1941-899X 2013, Vol. 5, No. 3

Clearly, for developing of this process, the positive points in common investment funds should be strengthened, to lead more investors to take advantages of the funds. The purpose of this paper is introducing the common investment funds to develop and strengthen funds more and lead more investors to take advantages of the funds. Research methodology of this paper is descriptive and content analysis by using reliable sources.

Keywords: Stock Exchange, mutual fund Investment, Return fund, Liquidity fund, Net Asset Value (NAV)

JEL Classification: D51, D53, E22, F31 


\section{Introduction}

In all societies, on the one hand, some people are faced with a surplus resources and on the other hand, many entrepreneurs with goog technical knowledge and practical experience have no necessary resources to invest. Meanwhile, efficient financial market are those that can arise from the exchange by providing various financial tools between households, enterprises and government. Common investment funds as one of the types of investment companies are financial intermediaries that sell shares to the public and receives funds and in the combination of a variety of securities such as stock, bonds short term money market instruments, other assets invest professionally. Common investment funds are financial instritutions of capital market, in recent years they have a special place in the market. The growth fund is represent the public interest in the national economy.

Ability to redeem shares of the fund or in other words, the liquidity of the investment funds units, and also variety of activities based on the investor's objectives, Using specialized management in managing portfolios, reducing the brokerage and operational costs in dealing with small investors, reducing the risk of investment through property financing portfolio diversification, are among the benefits that attract people to invest in these funds.

Performance of investment will be evaluated in two pillars of risk and return, and always the most return is the suitable standard for investment according to specific level of risk. The first aim of common investment funds is maximizing the return of assets under their management over time.

Clearly. If the financial instruments used in these institutions, which are used as models of investment, have great varieties, and enable to answer the aims, tastes, and spirt of sarings owner, in order to provide greater participation and make economic prosperity greater.

Research Literature

After world war I, the U.S seconomic development made small and large capitalsin the households, and their willingness to invest increased directly and indirectly on the stock. Thus, the first common investment funds stablished in modern from by the name of Massachusetts Investor trust, in 1924 in Boston. Since that year, investment funds have continued their activities in the world successfully. Only in the U.S, the number of common investment funds increase from 38 in 1940 to 8126 at the end of 2003.

Saeedi and moghadasian (1389): they did a study on the performance of common investment funds in Tehran stock Exchange, and found that there is no significant relationship between market returns and returns of investment funds after adjustment for risk.

Abdoh Tabrizi and sharifian (1387): They considered the effect of unfavorable risk on adjusted performance based on risks of investing companies listed in Tehran stock Exchange. Researchers in this study, have explained the differences in the performance evaluation critera based on modern portfolio theory and postmodern portfolio theory. In this study the relationship between rank companies are examined based on sharp criteria and desirable potential rato, and concluded that there is relationship between these two factors. That this 
relationship is due to the presence of negative skewness in the distribution of returns. On this bais, applying the desired potential have been diagnosed more plausibly.

Ja'fari sardasht (1386): in report of common investment fund identification, he has illustrated and introduced these funds in the world. Then, he made the points about common invectment funds in Iran. In this report, he has illustrated some needs of establishing fund, and fund problems in Iran.

Safar pour and sheykn (1386): they examined the performance of the ivestment companies based on stock portfolio and monthly stock returns. This study measured the impact of investment on firm performance. Corporate performance were evaluated by using of trainer, Jensen, and sharp criteria the results showed that companies with long - term and short term investments have the same function. The considered companies by using cash return and price index, have performance weaker than Exchange, and based on index of 50 active companies, they have performance equal to Exchange.

Safari (1381): he considered the performance of active investment companies in Tehran stock Exchange based on sharp and trainer criteria. He resulted that by increasing the number of shares in portfolio, unsystematic risk will redace. If the portfolios are various completely, performance ranking will close based on sharp and trainer indicators.

Swinkels and Rezingzak (2009): they evaluated the performance of common investment Funds that are active in polish market practically. Their study included three classes of investment funds; that is, shares fund, Balanced fund, and Bond fund.

Talatafza (2009): he examined the relationship between the size of the fund and fund's returns, and resulted that there is no relationship between the size of the fund and its return. Confirmation of impact of life fund, cost of fund, and trading activity of the fund's return is the other result of this study. Therefore, long - term funds have higher return.

\section{History of common investment funds in Iran and in the world}

Although the data of common investment fund refers to 18 th century in England, the first fund in modern from was established in Boston in 1924. Since that year, investment funds have continued their activities in the world saccessrfully.

Therefore, their investment increased from 488 million dollars in 1940 to 13.1 trillion by the end of 2010. Interestingly, the number of common investment funds increased from 546 in 1980 to 8548 in 2010. In 2010, over 51.6 million American households (equivalent to 43.9\% of households in the united states) had invested in funds. 90 million people are the number of investors who own $87 \%$ of the total assets of the funds, and the remaining value of assets belong to institutional investors. Other countries are also considering the importance of such funds to the formation and expansion of the investment funds. The first common investment fund was launched at 14/9/2007 in Iran.

Enterpreneur fund invests in fix income securities, every three months make a profit distribution, and guqaranteed minimum return of 16.5 percent for its invetors. Beside the funds with fixed income, funds investing in stocks have started their activities from the 
beginning of 2008. To the end of the first quarter of 2010, 37 active investment funds have been in Iran, four funds with fixed income and 33 share funds worked. Value funds invest in both fixed income fund and share fund has been more than 4100 billion Rials to the end of the first quarter of 2010. More than 8700 Legal investors invest in these funds.

\section{(Reports of securities and Exchange)}

\section{Common Investment Fund}

legal person is one who collects his funds from investment and invest in assets such as stocks, bonds, derivatives, and money market instruments. How asset allocation for portfolio managers is based on portfolio scientific principles and it is investment with growth objective, investment with objective of income, and investment to maintain assets.

The law defines the securities market of Islamic Republic of Iran as: it is a financial institution whose main activity is to invest in securities, and owners in proportion to their investment are partners in profit and loss of fund. (The Iranian parliament , November 22.2005)

Common investment funds provide the necessary fund through offering investment units to the public. And invest them professionally in various combination of securities such as, stock, Bond short - term instruments and other assets of the fund. Combination of assets in common fund is known as fund's portfolio or pannier. Bugers of investment units, gain a part of their share of fund's property. Each investment unit represent the property of each investors in fund's assets and income from that assets. (Jafferi seresht 2007,p.14)

Common investment fund give their shareholders the opportunity to accumulate their funds in the companies, and thereby reduce transaction costs by buging a bunch of stocks or bonds. Moreover common investment funds investe in various assets in the optimal portfolio. Shareholders can sell their shares at anytime and can determine the value of the shares nased on the value of the fund's portfolio. Investment funds are the effective instruments in the second market and organixe their activities on investment securities.

These funds obtained their own profits through transaction fees, cash dividend stocks or bonds, and increasing the value of securities fund.

At present, Iran Exchange are trying to launch gold funds, foreign exchange and real Estate. Attractive financial and capital markets, and record in the parallel market such as housing market in recent years has led investors to stock. New investors with lack knowledge not only does it hurt the group, but also prevailed the emotional attitudes in the capital market. These behaviors result from blindly follow of other investors and investment in these conditions can be based on rumors. Non - professional investors directed to funds, because the investors earn returns become loyal to capital investment. Common investment funds provide facilities for investors with different needs. Because the audience for common investment funds are non - professional investors in the market, it is necessary that strategic investment funds illustrate their goals, and their activities to achieve those aims. The analysis show that in addition to the investment fund's profit up 80 percent in some reaches, they have advantages 
that motivate their audience. These audiences are different groups of micro and macro customers. Although attractiveness of returns and benefits of this from of investment make their anits has sold quickly and reliably with development of culture of investment and need for more investors in more diverse forms of investment and concequently growth funds, focusing on marketing in the future is necessary.

Boom and bust of financial markets is very effective in these funds return. As the results showed, when Iran Exchange was encountered with reducing the size and value of transactions, investment funds index is decreasing. However, this reduction ws much less than the stock index. It seems that in conditions of downturn in the capital markets, the funds that have guaranteed profits are low risk alternative of investment. But it should be noted that lower risk has lower return. But no fund is not risk free, and all fund are associated with risk, and portfolio diversification only reduces the unsystematic risk. While it can be said that there is no risk - free security. Previously it was seen as a risk - free Treasuries of America. But with a lower credit rating of America, these securities are too risky.

\section{The main features of common investment funds}

Unique features of certail types of investment funds have a high flexibility and mobility. The main advantages and features are as follows:

1- External management and operations management by service providers: common investment funds are primarily institutions with assets in the securities from. The necessary tasks, operations, legal investments of them to be done by service providers outside of the organization. Thus, they can not be managed internally. Then, instead of providing a large organization, a small core is used for funds. For specialized tasks, such as managing portfolios of assets, marketing, and distribution of investment units, the experts are used. Applying professional management and making diversification in investment portfolio, reduced the risk of investing in the fund reasonably. The great savings arise for administrative costs and general fund in which increases the return on investment in the fund.

2- simplicity: simplicity is one of the features of common investment funds in investment for micro investors. Due to the possibility of coercion or redemptions by the fund, shareholders are able to sell their slocks any time after the end of the working clay.

3- variable capital, selling and redemption of stock continuously without limit: common investment funds have variable capital investment with open capital that will purchased the shares by the net asset value, and ofter new shares to investors continuously, and it allows small investors to invest indirectly in a variety of securities. This causes the liquidity of the units become very high from the perspective of investors, and recession and market problems may not have much effect on their liquidity.

4- daily share price based on the net value per share of the fund (NAV) for the sale and redemption of shares: fund will price its investment unit based on the net asset value of the fund securities continuously, and based on that price the units will sell and redeem. 
5- ke investment option of all or part of the income in the fund by share holders: it is possible for investors to immediately benefit from the fund, the fund will invest in it again.

6- no authority or instititution dose not guarantee principal or interest of investment in the funds.likeother companiesm, the fund can be profits or losses. Because the value of the securities in the portfolio. Increases or decreases. And certion institutions are not immune the investors against the risk. (common investment funds Regulations, 2007,p.8)

\section{Types of common investment funds}

Common investment funds depending on the type of secureties which invested are classified in different types. One devision is as follows:

1- mony market mutual funds investments: They are funds that are investing on short - term securities with maturities up to one year. They search fixed interest or short term interests. These characteristics are low - risk and low - return. (especially at low rates of interest)

2- stock market mutual funds investment:

The funds in stocks included a wide range of funds and investment. The main objective of long - term investment funds is obtaining the minimal cash income and investment.

These funds primarily are investing on equity, and stock selction is based on the fund's objectives that can invest in high dividear paying companies that are experienced and older, or newly established investment firms that are seeking growth.

\section{3- Fund of debt / fixed income securities fund :}

These funds primarily invest on government or corporate bonds, and their main purpose is to generate revenue. Unlike conventional loans, loan funds has no maturity or guaranteed capital repayment.The funds invest on corporate bonds, government and munieipal bonds, and the fund's main investors are conservative investors and retirees.

4- Common Fund investment hybrid / mixed Funds: This group of funds are investing on set of assets such as stocks, bonds and money market securities, and based on the current situation and forecasting the future trends of market, the appropriate combination of different securities according to the fund's objectives and policies are placed in its portfolio. So investors have high variety and flexibility in the choice. This fund is suitable for people who are following the combination of security, cash income, and investment.

\section{Advantages and disadvantages of common investment funds}

\section{A. Advantages}

Generally, the advantages of common investment fund are:

1- professional management: Professional management is one of the important advantages of common investment funds. With regard to financial ability, having enough information about market, skilled yraders of securities, mutual funds are able to attract and hire professional 
managers to invest on the stock Exchange and capital market. There fore, in most cases, their portfolio show the best combination of shares .

2- stock diversification and risk reduction: Through investment funds, in diverse mix of securities in different companies and industries, and also by using trust to maintain the stock, funds provide risk reduction.

3- high liquidity: Buy and sell shares of the fund through all the working days, delay problems are resolving in buy and fell securities. In regard to net assed value of the fund, and after deducing related expenses, investors at any time may have made all or some of the invest units to money and in terms of waiver.

4- using a small capital: in many cases, investors are unable to save substantial funds for investment. With limited funds to invest in a lot of alternative is impossible, and funds may provide small investment and low - risk investment.

5- recluce some of the costs: for various operations such as market research and large - scale transaction, fee is reduced.

6- flexibility/ variety: there are many different types of investment funds with a wide range of goals, from concervative to daring, they provide choice and flexibility of investment to investors.

7- accessibility: Easy access and purchase of shares by investors directly or indirectly.

\section{B. Dis advantages and potential risks}

In lack of proper management of funds, investment in them can also be disadvantages:

1- Risk management: managers are not infallible, and when the fund losses, they received their salaries. Specially, if changing the incompetent managers simply not possible legally, further problems could aries: if a significant portion of executive salaries is based on the fund's annual income, this problem will occur less.

2- the low efficiency of the possession of a certain portion of the fund than to return of ownership of the shares directly. (Due to the cost funds)

3- Having certain costs: Although the investment is cheaper than buying and selling a single share, it is not without cost.

Because there are some operating cost, and in cases, purchase or redemption of shares.

4- Dilution: Due to the large diversification, high yield of various companies of fund has lost among companies, and has little effect on the earnings of the fund. Dilution may also be the result of enlargement process of successful funds. Management van not find the previous successful investment for new ,oney and funds, and the efficiencies gained from new money.

5- Inactivity during office hours: stocks at the end of each working day after the close of the market is supplied.

(Nazarpour et.al 2009 , p12) 


\section{Macrothink}

\section{Return on mutual funds}

The oveall investment objective of the fund, is providing investors expected returns while investment risk is minimized.

Fund returns including changes in the value of the fund plus any income earned during the period of performance. In general the evaluation of fund return can be defined in changing in NAV, plus cash payments (D), and capital interest payments (c).

$\mathrm{R}_{\mathrm{p}}=$ fund return

$\mathrm{NAV}=$ net asset value

$\mathrm{D}_{\mathrm{t}}=$ cash profit payment

$\mathrm{C}_{\mathrm{t}}=$ capital interest

Incomes of investment fund

1- cash interest or dividends $\quad 2$ - increasing of share price

Calculation of investment return in funds:

Cash return: cash dividends per share of the fund as a percentage of NAV that is paried to the investor over the years.

$$
\text { Yield }=\frac{\text { payment per share }}{\text { price per share }}
$$

The total efficiency: the sum of the change fund than to the cash payments during an intial investment.

$$
\text { Total Return }(\%)=\frac{\text { Change in value }+ \text { dividends }}{\text { Cost of Initlal in Investment }}
$$

(Raei \& Pouyanfr 2011,p.410)

\section{Cost mutual funds}

Costs are the largest problem of mutual funds. Alarge part of the return are eaten by costs, and in most cases, the cause of the poor performance of the funds is their costs. Content addressed in this paper is that mutual fund industry are hidden these costs admidst the financial complexities and non - ambiguous words. Some critics belive that because many of the costs to be imposed on these funds is that most arerage investors do not know how to payment.

Funds received fees can be summarized in two parts.

1- Annual expenses that are spending for fund operating.

2- Transaction costs that are paied in buying and selling shares of fund. 
Cost of fund current expense is shown by cost ratio, and sometimes it is called by the management expense ratio.

A- Hire cost of fund manager: These costs are also known to management fee is a bout half to one percent of the fund's average assets. Although apparently there is not a high income, this income causes to managers of those funds put in the high - income countries. Statistic show that a small fund is equivalent to the average assets of 250 miliion dollars, and one percent of that will be 2.5 million dollars. A lthough it is true that the costs for management is essential high paid management will not be the high performance of the fund.

B- Administrative costs: Administrative costs in clued essential costs such as the cost of post, bookkeeping, customer service, replication, etc. some funds have special skill to minimize the costs. However, the cost varies from two thousand to two percent (for private funds). Mutual fund of stocks are in the range of $1.3 \%$ to $1.5 \%$.

C- Brokerage costs: These costs are those which will paid by fund due to the sale of shares. Important issue in this context is that investors should pay attention that investment funds with sales intermediaries are not acting.

C.1- Lnaugural brokerage fees: This kind of costs is the simplest kind of brokerage costs, These costs are paid when stock of mutual funds are buying. For example, if 1000 dollars is invested in a mutual fund which has $5 \%$ first brokerage fee. 50 dollars will give to sales dealer, and 950 dollars will invest.

Fund's share value when shopping = NAV + brokerage costs

C.2- closing costs of brokerage: These costs are knowe as postponed sales costs. The reality of these costs are a little complexed. The costs will be paid when the shares will sell in certain thme. A simple example of this kind of costs is $6 \%$ commission rate that reduees slowly to zero in the serenth year. If the shares is sold in the first year, the commission rate is $6 \%$ and if it is sold in the second year you pay commission rate of $5 \%$, and this rate reduce $1 \%$ each year until. That there is not any commission rate in the seventh year.

Stock value of fund in selling $=\mathrm{NAV}+$ closing cost of brokerage

C.3- without cost of brokerage: The cost of any commission will pay to fund's shares seller. In many cases, these funds are claiming, the money to pay commission is used from s service and are suitable to investment. Because of this, investors are looking for using the service of professional traders and tried to get higher returns. But there are no significant evidence to show the correlation between these costs and high return.

D- cost of sates: Operating expenses are not paid to the fund as commission directly. But it is a fraction of the total assets of the fund, and then reduces investment returns. For analysis of each fund status, the rato of operating expenses should be calculated to campare with other funds.

E- management commissions: Cost of investment is one of the main questions that will be discussed in relation to the mutual fund investment. All these types of expenses that investors 
pay funds are recorded under management commission. These cost provide all consumed fees by the fund. They are including rewards paid for the managers and agents of company. Management commission payable by a fund may be less than the amount that an investor should be paid to a stock broker. In fact the fund managers have an ability to buy and sell in high volume, which means that they can transact in the capital market and do transfers in connetion with broxers well. In addition fund managers have access to the types of investment that are not available to other people normally. The reward will be paid to the fund managers according to the type of their works is perfectly justified. (Mousavi et.al ,p8)

\section{The necessity create Mutual fund investment in Iran}

The necessities of creating mutual fund investment in Iran Necessities of creating mutual fund investment are illustrated from capital market of country long ago. Many efforts in this direction have been done, but no concrete result achieved. But after the new law of securities market of Iran in November 2005, and removing the obstacles ahead, the required Guidelines are compiled by the stock. Then many funds have been created, and activated in this industry. In our country stock, one of the problems that most listed companies in general and investment companies in particular are faced by, is a shortage of liquidity. In creasing of encumbrance and frequent capitals in recent years show the evidence of this claim. Reality of open capital of mutual funds solve the available problems of investment company's share holders in the complexity of capital increasing. The other hand, large number of companies are applicant to enter in to stock Exchange currently. With considering the policy of privatization of governmental companies, especially banks and insurance companies, the need for liquidity in the stock Exchange will be doubted. Absorption of liquidity are provided by mutual fund through absorption of micro - capital. Even in some cases, Absorption of liquidity is provided by people monthly allowance, allow more and fast transaction on the new shares of the stock Exchange.

In general, some of formation funds necessities are:

1- help to deepending and expanding the capital market through: Entry of new and active financial institution in the market and increasing transactions, possibility of household investment with low income and saving in the market, shift investment of households from banking system to capital market with increasing of liquidity, reducing risk and providing the suitable tools for investment and access to market, mechanism of maintaining the investors, and increasing the loyalty to market, and increasing of attracting new investors especially amataurs can assist to develop the capital market.

2- Resolving the shortage of liquidity in investment companies: through attracting the small capital of households and surplus assets of companies we can solv the liquidity problems of companies.

\section{3- helping to control the inflation}

Funds through the introduction of new financial instruments and absorption, and leading a portion of the wandering liquidity of people and investing in production and supplying section can reduce the inflation and unemployment. 
4- privatization policy and implementation of article c, 144 section of constitution: in regard to the accelerating economic growth and development based on implementation of social justice and poverty eradication in the context of country's twenty - year outlook document, and followed by transfer of economical activities and governmental companies to the private section and providing competitive structure and economic liberalization, we need to provide privatization instruments and active participation of investors.

5- helping to attract the foreign capitals: High risk and lack of confidence about the efficiency of economic activies is one of the agents of lack foreign investment. Common investment funds can reduce investment risk through diversifying of the portfolio, high strength of liquidity, economics in scale, and other factors. Lack of enough resources for analysis of company status, and misunderstanding of capital market is the other factor that foreigh investors clont enter to capital market of Iran. But simplicity of the fund's share price and the professional managers is useful to investors to updare information and following the development in the economic and stock of Iran.

6- providing a context for systematic and continuous investment: mutual fund investment provide a possibility to investment and participation in large economic activites for people with low and fixed income. The people who can not able to invest in the projects with low capital. On the other hand, because of awareness of available information in the capital market and more knowledge about it, fund managers provide the best portfolio with the most return and minimal risk for the people with morale risk averse (pensioners and ...). Also due to the high volume of cash in country on one hand, and economic activities need to cash in the other hand, stabilishing the mediatary financial entities such as common investment funds are necessary to creat logical relationship between investors and economic activists of the society. (Regulation establishing a joint fund to invest in Iran, 2007,p.78)

\section{Restrictions of investment funds:}

1- each fund must invest at least $90 \%$ of their assets in the designed area and on the securities. The investment manager can invest the remaining $10 \%$ to the other securities.

2- the fund investment will be necessarily in securities which published by organizations, entites, and governmental and non - governmental companies. According to regulations and with the permission of the organization.

3- funds are not allowed to purchase the securities, to presale of securities and participate in trading common funds.

4- the fund can stabilish branches of overseas, after receiving the relevant license.

5- funds invested in other investment companies is limited. Funds many not invest more than $5 \%$ of shares owned by each company. Or fund can not invest more than $10 \%$ of its issues in any investment company.

6- the fund can not invest exceed $10 \%$ of its total asset in non - investment company, and more than $15 \%$ of its total assets in a particular industry. Also maximum fund invested in shares of a company can not exceed $10 \%$ of the investee company capital. 
7- the sum of cash and receivable accounts should not be less than $5 \%$ and more than $10 \%$ of total fund assets. (Regulation establishing a joint fund to invest in Iran, 2007,p.69)

\section{Problems formation mutual Fund investment in Iran:}

1- the lack of explicit definition of the legal status of funds in commerce law.

2- openness and variableness of fund capital and fixedness of capital based on commerce law.

3- closing the symbols and impossibility of accurate calculation of NAV to determine the price of fund investment units.

4- lack of knowledge of people with entity and mechanism of funds action.

5- lack probability of public confidence to funds in regard to mental field and histort of some fands.

6- lack of financial specialists with sufficient knowledge on to the method of governing funds.

7- possibility of problems with liquidity of investment fund units (due to the lack of an immediate sale of shares in the fund's portfolio) especially at time of downswing and invasion of investors revoke the investment units.

8- tax issues arising from the trading of investment fund units outside of stock.

9- fluctuations and instability of market and its negative effect on fund return. (Regulation establishing a joint fund to invest in Iran, 2007,p.80)

\section{References}

AbdoTabrizi, Hasan, \& Sharifian, rohallah. (2008). Risk-adverse effect on risk-adjusted performance of investment companies listed in Tehran Stock Exchange. Journal of Tehran Stock Exchange, 1(1), 35-70.

Alexander Puetz, \& Stefan Ruenzi. (2011). Overconfidence among Professional Investors: Evidence from Mutual Fund Managers. Journal of Business Finance \& Accounting, 38(5-6), 684-712.http://dx.doi.org/ 10.1111/j.1468-5957.2010.02237.x

David M. Blanchett. (2012). Fund Flows, Momentum, and Mutual Fund Performance. The Journal of Investing, 21(2), 83-91. http://dx.doi.org/ 10.3905/joi.2012.21.2.083

Farrell, James L. (1997). Portfoliio Management: Theory and Application. McGraw Hill, 2, 515-518.

Financial Information Processing Center in Iran. (2012). Investment funds, October 2. www.fipiran.com.

Jafari seresht, Dawood. (2007). Report Identifying investment fund. Development Research and Islamic Studies, Tehran, Iran 
John A Haslem. (2008). Why Do Mutual Fund Investors Employ Financial Advisors?. The Journal of Investing, 17(4), 91-94. http://dx.doi.org/ 10.3905/JOI.2008.17.4.091

John A. Haslem (2012). Mutual Fund Total Cost Construct. The Journal of Index Investing, 3(3), 27-33. http://dx.doi.org/10.3905/jii.2012.3.3.027

John C. Bogle. (1992). Selecting equity mutual funds. The Journal of Portfolio Management, 18(2), 94-100. http://dx.doi.org/ 10.3905/jpm.1992.409402

M. Christensen. (2013). Applied Economics Letters. Danish mutual fund performance, 20(8), 818-820. http://dx.doi.org/10.1080/13504851.2012.750415

Mousavi, Zahra \& et.al. announced a joint investment fund. Tehran University of Economic Sciences. www.ses.ac.ir

Nazarpour, Mohammad, \& Abrahami, Mahboubeh. (2009). Design Islamic mutual funds in the capital market. Journal of Islamic Economics Research, 9(33), 63 - 93.

P.K. Mishra. (2011). Dynamics of the Relationship between Mutual Funds Investment Flow and Stock Market Returns in India. The Journal of Business Perspective, 15(1), 31-40. http://dx.doi.org/10.1177/097226291101500104

R. Kasilingam, \& G. Jayabal (2011). Preference and Perceptual Mapping of Mutual Fund Schemes. Asia Pacific Business Review, 7(2), 48-59

Raei, Reza, \& Pouyanfr, Ahmad (2011). Advanced Investment Management. published and edited books of the Human Sciences, Tehran, Spring, PP.410-413.

Reports the Tehran Stock Exchange. (2012). Available from www.seo.ir.

Saeedi, ali, \& Moqaddasian, Iman. (2010). Performance evaluation of investment fund shares. Journal of Tehran Stock Exchange, 3(9), 5-24.

Skerratt, \& P. A. Taylor. (1979). An Arbitrage Rationale For Tests Of Mutual Fund Performance. Journal of Business Finance \& Accounting, 6(3), 373-400. http://dx.doi.org/ 10.1111/j.1468-5957.1979.tb01098.x

Stephan Jank, \& Michael Wedow. (2013). Purchase and redemption decisions of mutual fund investors and the role of fund families. The European Journal of Finance, 19(2), 127-144. http://dx.doi.org/10.1080/1351847X.2012.662908

Stephanos, Papadamou, \& George Stephanides. (2004). Evaluating the style-based risk model for equity mutual funds investing in Europe. Applied Financial Economics, 14(10), 751-760. http://dx.doi.org/10.1080/0960310042000243583

Swinkels, L., \& P. Rzezniczak, (2009). Performance Evaluation of Polish Mutual Funds Managers. International Journal of Emerging Markets, 4(1), 26-42. http://dx.doi.org/10.1108/17468800910931652

Talat A., \& A. Rauf (2009). Performance Evaluation of Pakistani Mutual Funds. Pakistan economic and social Review, 47(2), 199-214 


\section{Macrothink}

Journal of Management Research ISSN 1941-899X 2013, Vol. 5, No. 3

The Iranian parliament. (2005). Securities Market Law of the Islamic Republic of Iran. Tehran, November 22. Article 1, Section 20, Page 2.

The Tehran Stock Exchange. (2007). Regulation establishing a joint fund to invest in Iran. Research, Development and Islamic Studies, winter 